\title{
Corrigendum: Delivery of crop pollination services is an insufficient argument for wild pollinator conservation
}

David Kleijn, Rachael Winfree, Ignasi Bartomeus, Luísa G. Carvalheiro, Mickaël Henry, Rufus Isaacs, Alexandra-Maria Klein, Claire Kremen, Leithen K. M'Gonigle, Romina Rader, Taylor H. Ricketts, Neal M. Williams, Nancy Lee Adamson, John S. Ascher, András Báldi, Péter Batáry, Faye Benjamin, Jacobus C. Biesmeijer, Eleanor J. Blitzer, Riccardo Bommarco, Mariëtte R. Brand, Vincent Bretagnolle, Lindsey Button, Daniel P. Cariveau, Rémy Chifflet, Jonathan F. Colville, Bryan N. Danforth, Elizabeth Elle, Michael P.D. Garratt, Felix Herzog, Andrea Holzschuh, Brad G. Howlett, Frank Jauker, Shalene Jha, Eva Knop, Kristin M. Krewenka, Violette Le Féon, Yael Mandelik, Emily A. May, Mia G. Park, Gideon Pisanty, Menno Reemer, Verena Riedinger, Orianne Rollin, Maj Rundlöf, Hillary S. Sardiñas, Jeroen Scheper, Amber R. Sciligo, Henrik G. Smith, Ingolf Steffan-Dewenter, Robbin Thorp, Teja Tscharntke, Jort Verhulst, Blandina F. Viana, Bernard E. Vaissiére, Ruan Veldtman, Kimiora L. Ward, Catrin Westphal \& Simon G. Potts

Nature Communications 6:7414 doi: 10.1038/ncomms8414 (2015); Published 16 Jun 2015; Updated 18 Feb 2016

The authors inadvertently omitted Kimiora L. Ward, who managed and contributed data, from the author list. This has now been corrected in both the PDF and HTML versions of the Article.

This work is licensed under a Creative Commons Attribution 4.0 International License. The images or other third party material in this article are included in the article's Creative Commons license, unless indicated otherwise in the credit line; if the material is not included under the Creative Commons license, users will need to obtain permission from the license holder to reproduce the material. To view a copy of this license, visit http://creativecommons.org/licenses/by/4.0/ 